\title{
SENSE, REFERENCE, DAN GENRE NOVEL MERAHNYA MERAH KARYA IWAN SIMATUPANG (ANALISIS HERMENEUTIKA PAUL RICOEUR)
}

\author{
Aslan Abidin \\ Fakultas Bahasa dan Sastra Universitas Negeri Makassar \\ Jl. Dg. Tata Raya Kampus Parangtambung \\ Email: aslanabidin@yahoo.com
}

\begin{abstract}
Sense, Reference, and Genre Merahnya Merah Novel by Iwan Simatupang (Hermeneutic Paul Ricoeur analysis). Paul Ricoeur's her meneutic theory call edautonomousmeaningfulliterarytextsofthe writers' intentions. Textis notonly are flection of the author's psychological and sociologi calcon text in which the tex twas produced. Meaning of the text can be traced from his relationship with the text bythe meaning (sense), the relationship with thetext-external world formed byreference(reference), can also be determined by the meaning of a literary genre. The text in the novel Merahnya Merah, Iwan Simatupang work, shows that poetic sense of meaning by reference is indeed possible. Dialectic between sense with reference means thedialecticbetweenthe text's meaning to the event. Meaning it is supported also by the nature of the genre's novel.
\end{abstract}

\begin{abstract}
Abstrak. Sense, Reference, Dan Genre Novel Merahnya Merah Karya Iwan Simatupang (Analisis Hermeneutika Paul Ricoeur). Teori hermeneutika Paul Ricoeur menyebutteks sastra bermakna otonom dari maksud penulisnya. Teks bukan hanya refleksi psikologis dan sosiologis pengarang dari konteks tempat teks diproduksi. Makna teks dapat ditelusuri dari hubungan teks dengan dirinya oleh makna (sense), hubungan teks dengan dunia-luar dibentuk oleh referensi (reference), makna juga dapat ditentukan oleh genre sebuah karya sastra.Teks-teks dalam novel Merahnya Merah karya Iwan Simatupang menunjukkan makna sense yang puitik dengan reference yang memang mungkin terjadi. Dialektika antara sense dengan reference berarti dialektika antara makna teks dengan peristiwa. Makna itu masih didukung pula oleh sifat teks yang ber-genre novel.
\end{abstract}

Kata Kunci: Otonomi semantik, sense, reference, genre.

Teks dalam sebuah karya sastra merupakan teks yang telah mengalami fiksasi atau pembakuan. Makna dari teks itu kemudian menjadi otonom, terpisah dari peristiwa atau konteksnya semula. Teks yang maknanya otonom, berarti tidak tergantung kepada maksud pengarang. Sebab maksud maupun ide pengarang, yang semula mungkin tergantung pada situasi psikologis-emosional pengarang, dapat saja berubah. Sementara maksud teks, yang telah tersusun dalam gramatika tata bahasa tertentu, telah dibuat fix atau dibakukan secara semantik dalam bentuk tulisan.

Selanjutnya, teks juga menjadi otonom dari audiens tertentu yang semula mungkin ditujukan oleh penulis. Teks bisa saja menyebar luas dan dibaca orang dari berbagai usia dan dalam kurun waktu yang lebih panjang. Otonomi semantik sebuah karya sastra kemudian menjadi rangkap tiga, otonomi makna dari intensi penulisnya, pembaca awal, dan dari situasi budaya asalnya. Dunia teks dalam karya sastra menjadi terbuka ke banyak audiens, melampaui ruang dan waktu dari penulisnya, serta memasuki dan mengalami pemaknaan baru dari waktu ke waktu.

Ignas Kleden (2004:108) yang mengutip Paul Ricouer, mengandaikan teks sebagai dunia tersendiri, yang lebih dari sekadar refleksi dunia psikologis pengarang, atau 
refleksi dari dunia sosiologis dari konteks di mana teks tersebut di produksi. Hubungan dengan penulis dibentuk oleh intensi, hubungan teks dengan dirinya oleh makna (sense), sedangkan hubungan teks dengan dunia-luar teks oleh referensi (reference).

Paul Ricoeur membagi makna menjadi dua, sense dan reference. Sense adalah apa yang dikatakan (what is said), sedangkan reference adalah jawaban atas pertanyaan: tentang apa sebenarnya sesuatu dikatakan (about what something is said). Sense diproduksi oleh hubungan-hubungan teks sendiri atau hubungan-hubungan dalam teks. Reference diproduksi oleh hubungan-hubungan teks dengan dunia luar-teks. Pada titik ini, wacana adalah dialektika antara sense dan referencenya.

Kleden mencontohkan pembedaan pengertian dalam berbahasa sebagai berikut: (misalnya kalau kita bercerita tentang kenaikan harga beras) terjadi suatu peristiwa (event) di mana kita melakukan tindakan berbicara (speech act). Sebagai peristiwa atau tindakan berbicara, peristiwa itu akan segera berlalu. Setelah selesai bercakap, pembicaraan itu selesai dan yang bercakap berlalu, apakah yang tertinggal? Menurut Ricoeur, yang tertinggal adalah makna (meaning).

Namun demikian, makna yang tertinggal itu hanya mungkin terwujud dalam peristiwa yang berlalu. Makna dalam pengertian ini berarti apa yang yang dikatakan (what is said). Dengan demikian, wacana (discourse) dalam pengertian Ricoeur, adalah dialektik antara peristiwa yang berlalu dan makna yang menetap. Setiap wacana hanya mungkin diwujudkan sebagai peristiwa, tetapi hanya bisa dipahami sebagai makna (Kleden, 2004:167).

Selanjtunya, Kleden mengungkapkan bahwa referensi dapat bersifat deskriptif kalau menyangkut sesuatu yang empiris, dan dapat bersifat poetis kalau menyangkut dunia nonempiris, tetapi merupakan dunia yang potensial, dunia yang dibangun dan masih harus dibangun. Referensi deskriptif tidak selalu bersifat ostensif atau menyangkut suatu lingkungan konkret, tetapi dapat berupa suatu dunia empiris yang tidak dapat dirujuk kepada suatu tempat dan waktu tertentu.

Makna tekstual adalah makna yang terbangun dari hubungan antar-tanda yang ada di dalam teks. Sedangkan makna referensial disebut juga makna kontekstual - terbangun antara teks dan dunia luar. Ricoeur membagi lagi acuan referensial ini menjadi dua, yakni acuan ostensif dan acuan non-ostensif. Acuan non-ostensif dibedakan lagi menjadi acuan deskriptif kalau menyangkut hal yang empiris dan acuan puitik kalau menyangkut dunia nonempiris, tetapi potensial untuk dibangun atau dunia yang mungkin terjadi. Referensi deskriptif tidak selalu bersifat ostensif atau selalu menyangkut lingkungan konkret, tetapi dapat berupa suatu dunia atau kejadian empiris, yang tidak dapat dirujuk ke suatu tempat atau waktu tertentu.

Makna referensial ostensif adalah makna yang dapat diperiksa dan ditemukan di dunia empiris di luar teks. Sedangkan makna referensial deskriptif adalah makna yang dapat diperiksa dan ditemukan dalam dunia empiris yang direka di dalam teks. Kedua dunia makna itu -sense dan reference- menurut Kleden, berada dalam dialektik yang hidup. Hal itu disebabkan, teks tidak hanya bercerita tentang referensi, tetapi teks membuka horison kepada suatu dunia yang dibangunnya sendiri. Dunia tekstual dan dunia empiris diperhadapkan, dan yang selalu menegangkan adalah bagaimana ketegangan itu dikelola, diperkuat dan diselesaikan oleh pengarangnya. Kleden mencontohkan bahwa dalam puisi, referensi dibatalkan sama sekali supaya seluruh kemampuan makna dikerahkan untuk memperkuat makna teks. Sebaliknya, dalam laporan penelitian sosial atau jurnalistik, makna teks ditekan seminimal mungkin untuk memaksimalkan dunia empiris ostensif. Menurut Kleden, posisi novel dan cerpen berada di tengah kedua makna tersebut.

Penelitian akan fokus menganalisis sense, reference, dan genre terhadap objek material berupa teks novel Merahnya Merah karya Iwan Simatupang yang ditulis dalam bahasa Indonesia ejaan Soewandi setebal 160 halaman dan diterbitan PT Gunung Agung di Jakarta tahun 1968. Teks novel Merahnya Merah yang dianalisis terutama di bagian deskripsi awal novel serta latar belakang tokoh-tokoh novel Merahnya Merah. Sementara objek formalnya akan menggunakan teori hermeneutik mengenai sense, reference, dan genre yang dikembangkan oleh Paul Ricoeur. 


\section{Sense, Reference, Genre}

Teks merupakan sebuah wacana atau diskursus yang telah difiksasi atau terbakukan lewat tulisan. Pembakuan tersebut merupakan ciri kontitutif dari teks. Sementara apa yang dibakukan oleh tulisan adalah diskursus dalam bentuk apapun yang dapat diucapkan (Ricoeur, 2009: 196).

Teks ditulis karena tidak diucapkan. Akan tetapi, pembakuan melalui tulisan menempati posisi ucapan atau berlangsung di tempat di mana ucapan bisa muncul. Hal itu menegaskan bahwa sebuah teks benar-benar menjadi sebuah teks apabila ia tidak terbatas hanya untuk mereproduksi ujaran yang telah diucapkan. Sebuah teks baru menjadi teks ketika ia langsung membubuhkan apa yang dimaksudkan oleh sebuah diskursus ke dalam huruf-huruf tertulis (Ricoeur, 2009: 197).

Hal tersebut di atas juga berlaku bagi teks sastra seperti novel. Novel merupakan bentuk sastra yang unik karena berada dalam tarik-menarik yang lebih kompleks antara peristiwa dan makna di satu pihak, serta dunia referensial dan dunia tekstual di lain pihak. Mengapa makna (meaning) begitu penting? Pertama, karena peristiwa akan berlalu, tetapi makna akan tetap tinggal. Kedua, makna teks adalah dunia tersendiri yang berbeda, baik dari maksud pengarang, maupun dunia referensial yang dirujuk oleh teks.

Ricoeur menyebut maksud pengarang sebagai utterer's meaning (makna pengujar), sedangkan makna teks adalah utterance meaning (makna ujaran). Makna pengarang atau pengujar sangat bergantung pada maksud pengaranganya, dan bersifat intensional. Sedangkan makna teks tergantung dari hubungan-hubungan identifikasi dan predikasi dalam teks, dan karenanya bersifat proposisional.

Menurut Ricoeur, makna bahasa selalu bersifat ganda. Kalau makna muncul dari dalam hubungan-hubungan yang ada dalam teks itu sendiri, maka pembaca mendapatkan sense atau makna teks. Selanjutnya, apabila makna lahir dari hubungan antara teks dengan dunia di luar teks, maka pembaca mendapatkan apa yang disebut sebagai reference atau referensi. Ketika diterapkan dalam karya sastra seperti teks novel, dapat dikatakan bahwa dialektika antara sense dengan reference dalam praktiknya berarti dialektika antara makna teks dengan peristiwa (Kleden, 2004:129).

Makna teks berbeda dengan dunia referensi. Hal itu disebabkan teks tidak hanya bercerita tentang referensinya, tetapi juga membangun dunianya sendiri, yang bisa saja berlainan atau bertentangan dengan dunia referensinya. Setiap teks yang hadir kemudian mendapatkan semacam otonominya sendiri, yakni otonomi semantik, yang selain sanggup membebaskan teks dari maksud pengarang, juga dapat membebaskan dirinya dari rujukanrujukan ke dunia referensial.

Jika sense itu imanen terhadap wacana,
dan objektif dalam arti ideal, reference
mengungkapkan gerak di mana bahasa
melampaui dirinya sendiri. Dengan kata
lain, sense berkorelasi dengan fungsi
identifikasi dan fungsi predikatif dalam
kalimat, dan reference menghubungkan
bahasa dengan dunia. (Ricoeur, 1996:21)

Selain itu, Ricoeur juga mengungkapkan bahwa sebuah wacana yang utuh dan berstruktur, bukanlah sebuah entitas yang tertutup. Sebuah teks dapat berkaitan dengan teks yang lain. Teks sebuah novel dapat saja mempunyai hubungan dengan teks novel lain, drama, sebuah sajak, bahkan berita di koran atau "teks" dari media audio-visual. Sehingga pemahaman atas sebuah teks, tidak hanya tergantung pada makna tekstual dan reference-nya, tapi juga dapat berhubungan dengan intertekstualnya.

Sementara genre sastra berhubungan dengan karya sastra sebagai produk budaya yang dihasilkan sastrawan dalam situasi sosialbudaya tertentu. Sebuah karya sastra, selalu berada dalam pengaruh literer karya-karya sastra sebelumnya. Hampir tidak mungkin seorang sastrawan melahirkan sebuah karya sastra, tanpa mendapat pengaruh dari keadaan sosial-budaya maupun karya sastra - baik yang lisan maupun tulisan sebelumnya.

Jenis atau genre karya sastra yang akan dibuat pengarang, bahkan hanya dapat diketahuinya dari masyarakat budayanya, termasuk lewat tulisan. Genre dapat menjadi cara awal pengarang menyampaikan "pesan" kepada calon pembacanya. Sebuah "genre" yang tidak dikenali pembaca, tidak akan dipilih pengarang karena "pesan" awal serta ide di 
dalam karyanya, akan tidak ditanggapi pembaca.

Itu juga berarti bahwa genre merupakan "tata tertib" tersendiri, aturan yang telah "disepakati" oleh pengarang dan pembaca dalam menyampaikan dan menerima pesan. Jenis sastra adalah suatu "lembaga" yang hidup, sebagaimana dikatakan Rene Wellek dan Austin Warren. Sehingga genre sastra juga bukanlah suatu "lembaga" yang bersifat tetap atau bersifat statis, ia bisa saja berubah.

Penggunaan bahasa (speech act) banyak ditentukan oleh konvensi, situasi, serta aturan-aturan non-verbal yang turut menentukan berhasil tidaknya sebuah bahasa digunakan sebagai alat dalam berkomunikasi. Demikian juga karya sastra, keberhasilannya turut ditentukan oleh ketepatan pemakaian konvensi oleh pengarangnya. Keberhasilan itu berhubungan dengan pengenalan, pemahaman, dan penerimaan masyarakat pembaca atas genre yang dipilih pengarang.

Makna dari genre kemudian berimplikasi kepada "logika" penerimaan dan pemahaman pembaca. "Ide genre memiliki fungsi heuristik penting dalam interpretasi," kata ED Hirsch Jr. "The logic of implications is always, therefore, the genre is logic, as common sense tell every interpreter" (Hirsch, 1979:91).

Pengarang bergerak-berkreativitas berdasarkan genre yang telah dipilihnya. Genre itu sekaligus mengaturnya dengan separangkat kaidah yang merupakan sarana dari genre itu untuk melahirkan jenis karya sastra tertentu, misalnya novel. Sementara pembaca, berdasarkan pengalaman sosial-budayanya, termasuk dalam membaca sastra, dapat terbantu pemahamannya untuk menerima atau menolak sebuah genre sastra tertentu.

Kesenangan orang terhadap karya sastra berasal dari gabungan rasa senang karena mendapatkan sesuatu yang baru dan karena mengenali halhal yang terdapat dalam karya sastra. Genre menampilkan keseluruhan teknik estetis yang dapat dipakai oleh pengarang dan sudah dipahami oleh pembaca. Pola yang terlalu umum dan penuh pengulangan akan membosankan pembaca, sementara pola yang sama sekali baru akan sulit dipahami pembaca. Penulis yang baik akan menyesuaikan diri dengan genre yang ada (Wellek-Warren, 1989:312).

Genre sastra merupakan prinsip-prinsip spesifikasi yang menempatkan karya sastra dalam tipe-tipe tertentu. Menurut Ricoeur, karya tunduk pada bentuk kodifikasi yang diterapkan pada bentuk komposisi dan mengubah wacana menjadi cerita, puisi, esai, dan lain sebagainya. Genre merupakan ciri distingtif semua wacana yang mengalami fiksasi, baik berupa karya sastra maupun yang non-sastra.

Pendekatan genre memperlihatkan nilai yang jelas dengan memperhatikan perkembangan internal karya sastra atau "genetika sastra", sebagaimana diistilahkan Henry Wells yang dikutip Wellek dan Warren. Sebuah buku juga dapat meniru, memparodi, atau mengubah buku lainnya secara simultan maupun kronologis. Genre modern dapat saja terkait dengan genre primitif seperti sastra lisan atau sastra rakyat. Menurut Shklovsky, bantukbentuk seni baru, hanyalah merupakan kanonisasi genre-genre sebelumnya yang lebih rendah.

Gambaran Shklovsky di atas terjadi pada novel. Wellek dan Werren menyebutkan bahwa sebelum mencapai bentuk novel seperti sekarang ini, novel hanya berbentuk sederhana serupa surat, buku harian, catatan perjalanan, memoar, esai, sampai berupa drama. Bentuk lain yang serupa novel adalah roman. Novel, berdasarkan pandangan Clara Reeve yang dikutip Wellek dan Warren, didefenisikan berisi gambaran dari kehidupan dan perilaku yang nyata, dari zaman pada saat novel itu ditulis.

Secara stilistika, novel menekankan pentingnya detail, dan bersifat mimetis dalam arti sempit. Sedangkan roman merupakan kelanjutan dari dari epik. Roman mungkin mengabaikan kepatuhan pada detail (misalnya dalam menyusun dialog yang mirip cara berbicara orang dalam kenyataan). Novel lebih mengacu pada realitas yang lebih tinggi dan psikologi yang mendalam (Wellek-Warren, 1998: 282).

Sementara roman, yang ditulis dalam bahasa yang agung dan diperindah, menggambarkan apa yang tidak pernah terjadi 
dan tidak mungkin terjadi. Novel disebutkan bersifat realistis, sedangkan roman bersifat putis dan epik. Novel berkembang dari bentukbentuk naratif non-fiksi, seperti surat, jurnal, memoar, biografi, kronik, atau sejarah. Singkatnya, novel berkembang dari dokumendokumen.

\section{Analisis Sense}

Novel Merahnya Merah karya Iwan Simatupang, berkisah tentang seorang tokoh yang disebutkan sebagai: "Sebelum revolusi, dia calon rahib. Selama revolusi, dia komandan kompi. Di akhir revolusi dia algojo pemancung kepala pengkhianat-pengkhianat tertangkap. Sesudah revolusi, dia masuk rumah sakit jiwa."

Kutipan di atas sekaligus menjadi paragraf pembuka novel ini. Paragraf selanjutnya: "Kini revolusi telah selesai. Telah lama, kata sebagian orang. Ah! Barangkali juga tak selesai-selesai. Dia tak tahu. Rumah sakit jiwa telah pula lama ditinggalkannya."

Dia bukan rahib. Gereja tak pernah dimasukinya lagi. Terdaftar di departemen urusan veteran, dia tak tega pula. Dia tak tahu apa sebenarnya dia kini. Dia hanya tahu, di mana dia. Yaitu, di sepanjang jalan raya. Menurut istilah resmi departemen angkatan kepolisian dan departemen urusan sosial, dia orang gelandangan.

Demikianlah latar belakang tokoh digambarkan. Berbagai pekerjaan dan keadaan tokoh disebutkan. Bahkan melewati rentang waktu yang sebenarnya cukup panjang, yakni antara sebelum dan sesudah revolusi. Walau begitu, pengarang malah tidak menyebutkan nama tokohnya.

Novel selanjutnya bertutur tentang Tokoh Kita yang bertemu seorang perempuan usia 14 tahun bernama Fifi. Perempuan itu lalu dibawanya ke pinggir kota, di sebuah perkampungan gelandangan.

Tempat itu berupa sekumpulan gubukgubuk kecil yang memberikan gambaran suatu film kartun kanak-kanak. Kontrasnya dengan gambaran para penghuninya yang bukan kanakkanak lagi itu, memberikan pemandangan yang lebih khas lagi. Yakni, pemandangan dari semacam pekuburan di dunia surealis, mayatnya berkeliaran, semuanya menantang langit terang: Kami ingin hidup 100 tahun lagi!
Novel ini memberi gambaran yang jelas tentang latar belakang tokoh-tokohnya dengan agak lengkap. Fifi, keluarganya diperkosa dan dibunuh gerombolan. Ia ikut mengungsi ke kota dan terpaksa menjadi pelacur dan gelandangan.

Maria, dulunya bercita-cita jadi juru rawat, tapi gagal karena takut melihat darah. Ia lalu jadi pembantu rumah tangga pastoran di kota kecil tak jauh dari kampungnya. Pada satu petang, dia diterkam dari belakang oleh seorang laki-laki yang tak dapat dia kenali wajahnya yang menyeretnya ke samak-semak dan memperkosanya.

Seminggu sesudah itu, seorang pastor di pastoran itu mati gantung diri. Sebabsebanya tak diketahui. Maria begitu takutnya melihat pastor yang tergantung di tali itu, hingga dia lari dari pastoran itu. Lalu dia ikut salah satu perahu yang biasa mengangkut rempah-rempah ke Jawa, dan sampailah ia ke perkampungan gelandangan itu.

Bagian "perkenalan" dalam Merahnya Merah, memberi gambaran akan peristiwa yang cukup prosais. Malah pengutipan kalimat terkenal dari Chairil Anwar: "Kami ingin hidup 1000 tahun lagi!" membuat bagian ini sekaligus puitik. Detailnya penggambaran mengenai peristiwa dari latar belakang tokoh-tokoh, sebenarnya dapat membuat tokoh-tokoh ini dikatakan spesifik, tetapi karena detail tersebut berasal dari nasib-nasib yang umum dialami dan ditanggung kalangan masyarakat bawah, membuat tokoh-tokoh ini tidak spesifik tetapi stereotif.

Saking stereotifnya, sehigga nama tokoh utama tidak perlu disebutkan. Ia tidak hanya stereotif dari suatu golongan nasib -atau katakanlah kelas sosial bawah- tapi juga adalah wakil sekaligus produk dari suatu zaman yang disebut pasca-revolusi, atau secara ironi dapat dikatakan pasca-kemerdekaan. Tokoh utama, yang disebut sebagai Tokoh Kita, adalah wakil yang umum dari orang-orang yang berjuang di zaman revolusi, tapi mengalami nasib yang sangat buruk justru setelah Indonesia menjalani masa kemerdekaan.

Tokoh Kita bukannya tidak punya pilihan selain menjadi gelandangan. Ia mantan komandan kompi, anak buahnya banyak yang punya kehidupan yang baik dan bersedia menolongnya, tapi Tokoh Kita tidak melakukannya. Ia bahkan tidak tega terdaftar di departemen veteran. Pilihan Toko Kita menjadi 
gelandangan sebenarnya dapat dilihat pada penggambaran peristiwa masa kecil Tokoh Kita.

Dia lahir, terus dimasukkan oleh ibunya ke dalam tong sampah. Maksudnya, supaya dia ikut terbuang bersama isi tong itu. Tapi, kuli-kuli dari dinas kebersihan kotapraja segera melihat bayi dibungkus itu. Kotapraja menyerahkan bayi itu kepada panti asuhan yatim piatu yang tidak bersifat keagamaan. Berusia delapan tahun, dia lari dari panti asuhan itu. (Simatupang, 1968: 30)

Nasib buruk seperti yang dialami Tokoh Kita, bukan cuma dialami mereka yang dulu berjuang untuk merebut kemerdekaan, tapi juga dijalani banyak orang dari berbagai latar belakang kemalangan. Fifi dan Maria adalah hasil dari kekacauan pasca-revolusi di kampung mereka masing-masing. Fifi diperkosa, dan orangtua serta saudaranya juga diperkosa sebelum dibunuh gerombolan. Sementara Maria diperkosa orang yang tidak dia kenal, yang menyergapnya dari belakang.

Orang-orang ini kemudian bertemu, di tempat yang juga merupakan geografis-stereotif dari kalangan gelandangan, yakni di pinggir kota. Mereka ke kota -sebenarnya terseret ke kota - memang bukan untuk bertarung memburu penghidupan layak di pusat kota, kualitas orang-orang ini bukan dari jenis yang seperti itu. Fifi dan Maria adalah orang-orang dengan pilihan bertahan hidup yang sangat terbatas, tinggal di kampung yang tidak aman atau ke kota yang sedikit aman, dengan risiko terpaksa memperdagangkan tubuh agar dapat tetap hidup.

Fifi dan Maria di kota, tepatnya di pinggir kota, sebenarnya juga menghadapi segala ketidakamanan khas perkotaan. Fifi misalnya, disambut dengan razia oleh polisi yang kemudian menidurinya. Pada bagian akhir cerita, Fifi dikisahkan menghilang, sebelum diketahui mati terbunuh oleh Maria.

Pilihan Tokoh Kita, Fifi, dan Maria, untuk menjadi gelandangan, merupakan peristiwa yang "linear" dengan apa yang sebelumnya menimpa mereka. Toko Kita dilemparkan ke tong sampah begitu dia lahir, lalu ditemukan oleh kuli, merupakan gambaran peristiwa-peristiwa yang memang menggelandang. Sementara Fifi dan Maria adalah korban pemerkosaan, kemudian menjadi pelacur, merupakan peristiwa-peristiwa perkelaminan, yang karena dilakukan di kelas gelandangan, membuat mereka menjadi pelacur gelandangan.

\section{Analisis Reference}

Peristiwa-peristiwa dalam bagian perkenalan tokoh-tokoh novel Merahnya Merah adalah perihal yang mungkin dan dapat terjadi dalam realitas. Seorang bayi yang lahir, dibungkus plastik kemudian dilemparkan ibunya ke tong sampah, merupakan peristiwa yang sering terjadi hingga kini. Juga, bagaimanapun khasnya profesi Tokoh Kita, mulai dari calon rahib, komandan kompi, pemancung kepala pengkhianat, sampai gelandangan, adalah profesi yang dapat saja dialami dan melekat kepada satu orang.

Fifi dan Maria demikian pula. Orang dengan nasib seperti keduanya ada dalam realitas sehari-hari. Kisah perempuan yang diperkosa kemudian menjadi pelacur telah menjadi cerita klasik dalam dunia pelacuran. Pelacur kelas bawah, yang menggelandang tinggal di gubuk-gubuk kecil, juga bukannya tidak ada dalam kehidupan sehari-hari. Penggambaran mengenai gubuk-gubuk kecil yang seperti pekuburan, dengan penghuninya yang berkeliaran, juga dapat ditemukan dalam realitas.

Orang seperti Tokoh Kita, Fifi, serta Maria, dapat ditemukan di masyarakat gelandangan. Namun apakah mereka adalah tokoh yang persis dimaksud pengarang, tidak penting lagi. Makna teks bisa saja sangat kuat memberi gambaran mengenai sosok seperti Tokoh Kita. Sehingga ia dapat kita kenali ketika berpapasan dengan seorang gelandangan -dari pakaiannya yang lusuh dan ada borok di kakinya - tapi apakah dia Tokoh Kita yang dulu calon rahib dan pernah menjadi algojo pemancung pengkhianat, menjadi tidak penting lagi.

Kita mungkin bertabrakan dengan sosok gelandangan pelacur serupa Fifi dan Maria di sebuah pasar malam. Fifi yang gadis kecil usia sekitar 14 tahun, dan Maria yang agak gemuk dengan kulit hitam dan rambut keriting. Keduanya berpenampilan seronok dari 
bahan murah, memakai bedak dan gincu secara menyolok, serta bersikap genit, tapi apakah dia adalah Fifi dan Maria dalam Merahnya Merah, tak perlu lagi diusut.

Ini dikerenakan Tokoh Kita, Fifi, dan Maria, adalah acuan deskriptif dari dunia empris yang menjadi rekaan pengarang. Referensi deskriptif ini tak dapat ditelusuri secara pasti di dunia realitas. Kota dan kampung yang menjadi asal ketiganya, maupun kota yang kini menjadi tempat mereka menggelandang, adalah tempat-tempat yang tidak lagi penting. Tempat-tempat itu bahkan tidak disebutkan secara jelas oleh pengarang. Maria hanya disebutkan berasal dari bagian timur Indonesia, entah Maluku, Timor, entah Flores.

Selain penggambaran awal tokohtokoh, novel Merahnya Merah juga memperkenalkan tempat ketiga tokohnya, yakni perkampungan gelandangan di pinggir kota. Gubuk-gubuk dan gelandangan pada bagian ini, digambarkan Iwan Simatupang sebagai "pemandangan dari semacam pekuburan di dunia surealis, mayatnya berkeliaran, semuanya menantang langit terang: Kami ingin hidup 100 tahun lagi!" Gambaran di atas, walau juga bersifat deskriptif, tetapi lebih mengacu ke deskriptif puitik yang non-ostensif. Apalagi dengan adanya kutipan puisi dari Chailril Anwar, yang aslinya berbunyi "aku mau hidup seribu tahun lagi".

Bagian yang memasukkan kutipan puisi Chairil Anwar di atas, kalau semata mengacu atau berbicara tentang puisi Chairil Anwar, sebenarnya juga dapat bermakna ostensif. Puisi Chairil Anwar di atas, yang berjudul "Aku", dapat dilacak dan ditemukan dalam realitas. Hanya saja, untuk pemakaian kalimat itu dalam teks ini, Iwan Simatupang hanya meminjam maknanya sebagai penggambaran tekad para gelandangan, yang walau tinggal di gubukgubuk kecil yang seperti kuburan dan mereka seperti mayat yang berkeliaran; tetap betekad untuk hidup 100 tahun lagi!

Sehingga bagian kalimat di atas tetap merupakan deskripsi puitik non-ostensif. Kaitannya dengan sajak Chairil Anwar adalah seperti yang dikemukakan Ricoeur sebagai hubungan intertekstualitas. Teks, sebagaimana teks dalam Merahnya Merah, bukanlah sebuah entitas yang tertutup, tapi terbuka akan pengaruh oleh teks lain. Sehingga pemahaman atas teks ini, dapat berhubungan dengan intertekstualnya, yakni sajak Chairil Anwar yang berjudul "Aku".

\section{Analisis Genre}

Berdasarkan pandangan Clara Reeve bahwa novel berisi gambaran dari kehidupan dan perilaku yang nyata dari zaman pada saat novel itu ditulis, dapat dibuat beberapa pernyataan simpulan. Pertama, Meranya Merah adalah narasi panjang yang bersifat realistis. Kisah yang disajikan berlatar waktu peristiwa yang benar-benar terjadi, yakni masa revolusi dan sesudah revolusi. Latar tempat yang ditampilkan juga bersifat sangat mungkin ada dalam relitas. Merahnya Merah berisi gambaran dari kehidupan dan perilaku yang nyata, mulai dari zaman ditulisnya hingga kini.

Kampung Fifi, kantor polisi, serta polisi yang meniduri Fifi, sangat mungkin ada. Perilaku polisi yang seperti itu, juga bukanlah "fakta" yang mampu ditolak kejadiannya di Indonesia. Maria yang bekerja di dapur pastoral, diperkosa, lalu pastor yang gantung diri, gubuk Maria di pinggir kota, semuanya adalah tempat serta peristiwa yang dapat saja terjadi. Perahu dari entah Maluku, entah Timor, entah Flores, yang berlayar ke Jawa, adalah perahu yang sangat mungkin ada.

Kedua, Merahnya Merah berisi penggambaran yang detail. Latar belakang Tokoh Kita, latar belakang Fifi dan Maria, digambarkan dengan cukup jelas. Bahkan perasaan-perasaan Tokoh Kita mengenai eksistensinya, juga digambarkan secara rinci. Penggambaran ini antara lain dapat dilihat pada bagian ketika Tokoh Kita ikut menyaksikan penemuan mayat tak lengkap di sungai.

Mayat itu tak punya kepala lagi. Juga
tak punya kedua belah tangan dan
kakinya lagi. Tinggal hanya tubuh
bagian atasnya saja. Persis sebuah torso
dalam dunia seni pahat. Baunya busuk
sekali. Dia hampir mengurai.
(Simatupang, 1968: 33 ).

Penggambaran peristiwa yang detail di atas, masih ditambah lagi dengan penggambaran detail tentang isi pikiran Tokoh Kita. Pikiran Tokoh Kita itu bersangkut-paut mengenai keadaan dirinya sendiri. 
Pada mayat tak lengkap tadi, dia melihat kesimpulan paling ringkas dari nasibnya sendiri sekarang ini. Dan bersama nasibnya, juga nasib dari sekalian temannya kaum gelandangan lainnya. Manusia tak lengkap! Demikian otaknya menggitiknya terus. Manusia tak lengkap, apa jadinya? Apa namanya? Apa takdirnya nanti, sesudah perhitungan terakhir di depannya?

Merahnya Merah berisi banyak penggambaran mendetail. Detail peristiwa antar-tokoh, yang terjadi antara Tokoh Kita dan Fifi di sebuah lapangan misalnya, juga digambarkan dengan detail sekaligus bersifat mimesis dalam arti yang sempit:

Tangannya yang tak sengaja -dalam satu usaha dramatis menolak tubuh Fifi jauh-jauh dari dirinya -menyentuh buah dada Fifi, membuat kubu pertanahnnya yang terakhir rubuh, tumbang, hancur lebur. $\mathrm{Di}$ atas reruntuhan itu, pelan-pelan tapi pasti sekali, dirasanya datangnya nafsu birahinya. Nafsu kelamin laki-lakinya. Nafasnya sesak. Getar-getar kecil birahinya secara sistematis merebut seluruh tubuhnya (Simatupang, 1968:67).

Ketiga, Merahnya Merah juga mengacu ke realitas yang lebih tinggi, dengan tingkat "emosi" psikologik yang mendalam. Selain psikologik, Tokoh Kita bahkan selalu menghadirkan tanggapan-tanggapan filosofis yang tinggi. Keteguhannya untuk bersetia kepada dunia kegelandangan, dan menganggap perubahan nasib dari meggelandang ke memiliki tumah permanen, dikatakannya sebagai pemberontakan terhadap kegelandangan. Apalagi bila tidak memiliki organisme yang lengkap dan momen yang tepat untuk melakukan tindak pemberontakan tersebut.

Apakah sesugguhnya yang ingin dituju Fifi? Ringkasnya: pemberontakan. Pemberontakan terhadap statusnya sebagai manusia gelandangan. Menggerakkan mekanisme dari mobilitas sosial dan berusaha memasuki kelas kemasyarakatan lain, lebih tinggi dari kelasnya yang kini. Dalam pemberontakannya ini, Fifi telah melakukan apa yang seharusnya tidak boleh dilakukan dalam tiap pemberontakan. Yakni, unsur-unsurnya harus memulainya secara serempak (Simatupang, 1968: 80).

Semua ciri-ciri tentang novel yang sebelumnya disebutkan Reeve, juga ada di dalam Merahnya Merah. Sehingga dapat dikatakan kalau Merahnya Merah adalah sebuah jenis karya sastra yang berbentuk novel. Pembagian genre antara novel dan roman, bahkan antara seluruh karya sastra, seringkali sangat tidak ketat. Sebuah novel dalam sastra modern, bisa saja di dalamnya mengandung beberapa sub-genre yang berbeda.

\section{KESIMPULAN}

Novel Merahnya Merah, walauyang penulis analisis dalam kajian ini hanyalah bagian awal novel serta gambaran latar belakang dari tiga tokohnya, menunjukkan bahwa ketiga tokoh memiliki asal-usul dari kelas bawah yang serba susah. Ketiga tokoh berasal dari wilayah sosial dan ekonomi yang tidak "aman". Tokoh Kita dilemparkan ke tong sampah ketika bayi. Sementara Fifi dan Maria adalah dua perempuan korban pemerkosaan.

Ketiga tokoh juga sama-sama memiliki pengalaman dalam menyaksikan kematian. Tokoh Kita sebelumnya adalah algojo pemancung kepala pengkhianat. Ia juga pernah melihat mayat yang tidak lengkap terapung di sungai, sebelum akhirnya ia sendiri juga mati terpancung oleh golok centeng, yang pada saat yang sama juga mati tertembak oleh polisi. Sementara Fifi, orangtua dan saudaranya mati dibunuh gerombolan pemberontak. Lalu Maria yang pernah melihat pastor mati gantung diri. Maria kemudian membunuh Fifi dengan alasan cemburu atas kedekatannya dengan Tokoh Kita.

Bagian di atas, seolah memberi gambaran bahwa pembunuhan terjadi, baik di zaman revolusi bergolak, maupun setelah kemerdekaan Indonesia. Pembunuhan dan kematian yang lebih tragis -dengan alasan yang juga amat beragam - justru terjadi di era kemerdekaan. Tokoh Kita, yang berjuang sebagai komandan kompi dan pemancung kepala pengkhianat di zaman revolusi lalu berjuang lagi dalam kapasitasnya sebagai 
gelandangan untuk menolong Fifi, harus meninggal secara tragis dan ironis.

Tokoh Kita meninggal terpancung golok di tangan centeng di depan jejeran penegak hukum seperti inpektur, pangdak, pangdam, serta seorang dokter. Tak ada yang datang menolong dan menyelamatkannya. Novel ini seolah menampilkan ironi betapa seluruh tentara dan polisi di era kemerdekaan, bukan cuma tidak mampu menemukan Fifi ketika menghilang, tetapi juga tak dapat menyelamatkan Tokoh Kita dari kekacauan khas perkotaan.

\section{DAFTAR PUSTAKA}

Hirsch, ED Jr. 1979. Validity In Interpretation. New Haven and London. Yale University Press.

Kleden, Ignas. 2004. Sastra Indonesia dalam Enam Pertanyaan. Pustaka Utama Grafiti. Jakarta.

Ricoeur, Paul. 2009. Hermeneutika Ilmu Sosial. (Cetakan Ketiga) Kreasi Wacana. Yogyakarta.

Ricoeur, Paul. 1976. Interpretation Theory: Discourse and Surplus Meaning. Forth
Tokoh Kita dan Fifi terbunuh, Maria pergi ke biara di kaki gunung yang jauh, dan centeng mati diterjang peluru. Rentetan kejadian tragis itu membuat "hilang"-nya empat gelandangan dari perkampungan gubuk-gubuk gelandangan di pinggir kota itu. Akan tetapi, di sebuah kota dengan kekacauan pascakemerdekaan-yang pinggirnya memiliki banyak perkampungan gubuk-gubuk gelandangan-apalah artinya empat gelandangan, hilang atau dihilangkan.

Worth: Texas Christian University Press, Texas.

Ricoeur, Paul. 1996. Interpretation Theory: Discourse and Surplus Meaning (Teori Penafsiran: Wacana dan Makna Tambah). Diterjemahkan oleh Hani'ah. Pusat Pembinaan dan Pengembangan Bahasa. Jakarta.

Simatupang, Iwan. 1968. Merahnya Merah. Gunung Agung. Jakarta.

Wellek, Rene \& Austin Warren. 1989. Teori Kesusastraan. PT Gramedia. Jakarta. 